\title{
Penerjemahan Indonesia-Arab Papan Informasi Dan Petunjuk Arah Di Curug 7 Cilember
}

\author{
Moch. Syarif Hidayatullah \\ UIN Syarif Hidayatullah Jakarta \\ Anggun Eka Handayani \\ Program S1 UIN Syarif Hidayatullah Jakarta
}

\begin{abstract}
Abstraks
Penelitian ini bertujuan untuk memasyarakatkan dan meningkatkan peran bahasa Arab dalam dunia pariwisata. Untuk tujuan itu, peneliti menerjemahkan teks-teks pada papan petunjuk arah dan informasi yang berada di objek wisata ke dalam bahasa Arab. Proses penelitian ini dimulai dengan cara mengumpulkan data dalam bentuk foto, kemudian diterjemahkan ke dalam bahasa Arab. Setelah itu, peneliti membuat desain papan petunjuk arah dalam dua bahasa. Dalam penelitian ini, peneliti menggunakan metode research and development. Peneliti melakukan pengumpulan data, pengklasifikasian data ke dalam beberapa kategori, serta menganalisis data secara deskriptif dan nonstatistik. Penelitian ini juga berisi analisis data yang berisi sebuah pertanggungjawaban akademik dalam menerjemahkan dengan metode komunikatif. Penelitian ini menghasilkan sebuah media komunikasi visual berupa papan informasi dan petunjuk arah dalam dua bahasa (Indonesia-Arab) di Curug 7 Cilember, Megamendung, Bogor, Jawa Barat. Penelitian ini dapat digunakan sebagai model penerjemahan Indonesia-Arab papan informasi, petunjuk arah, dan lainnya di tempat wisata lain yang membutuhkan komunikasi visual dalam bahasa Arab.
\end{abstract}

Kata kunci: penerjemahan papan informasi, metode komunikatif, media visual, pariwisata

\section{Abstract}

This research aims to socialize and enhance the role of Arabic in the world of tourism. For that purpose, the researcher translated the texts on the directions and information in the tourist attraction in Arabic. The process of this research began with how to collect data in the form of photographs, then translated into Arabic. After that, the researchers designed the directions in two languages. In this study, researchers used research and development methods. Researchers conduct data collection, classify data into several categories, and analyze data descriptively and non statistically. This research also contains data analysis which contains an academic responsibility in translating with communicative methods. This study produced a visual communication medium in the form of information boards and directions in two languages (Indonesian-Arabic) at Curug 7 Cilember, Megamendung, Bogor, West Java. This research can be used as a translation model for Indonesian-Arabic information boards, directions, and more at other tourist sites that require visual communication in Arabic.

Keywords: information board translation, communicative methods, visual media, tourism 


\section{A. Pendahuluan}

Papan informasi dan petunjuk arah merupakan media komunikasi yang bersifat linear. Komunikasi linear maksudnya hanya terjadi satu arah, tanpa umpan balik terhadap pesan yang disampaikan komunikator terhadap komunikan. Pada proses linear, komunikator berupaya semaksimal mungkin agar komunikasi berjalan efektif. ${ }^{1}$ Sesuatu yang bersifat linear tentu harus disajikan seefektif mungkin. Hal ini disebabkan karena komunikator tidak mengetahui respon komunikan terhadap pesan yang telah disampaikan.

Salah satu hal yang menjadi perhatian dalam berkomunikasi secara efektif ialah kesamaan bahasa, karena bahasa merupakan wahana komunikasi utama manusia. ${ }^{2}$ Akan tetapi pada kehidupan sehari-hari antara komunikator dan komunikan tidak selalu berkomunikasi dengan menggunakan bahasa yang sama. Oleh karena itu, terjemahan sangat diperlukan dalam berkomunikasi untuk menyampaikan pemahaman kepada komunikan.

Penerjemahan papan petunjuk arah akan lebih efektif jika diterjemahkan dengan menggunakan metode penerjemahan komunikatif. Karena metode penerjemahan komunikatif sangat memperhatikan pembaca atau pendengar agar tidak mengalami kesulitan dalam memahami hasil terjemahan. Dengan menggunakan metode komunikatif hasil terjemahan papan petunjuk arah tersebut akan menjadi media pengantar komunikasi yang efektif bagi para wisatawan.

1 Onong Uchjana Effendy, Ilmu, Teori Dan Filsafat Komunikasi. Bandung (Bandung: Citra Aditya Baktu, 2003), 38.

${ }^{2}$ Ahmad. Sihabudin, Komunikasi Antarbudaya: Satu Perspektif Multidimensi. (Jakarta: Bumi Aksara, 2013), 88.

3 Burhan Bungin, Komunikasi Pariwisata (Tourism Communication): Pemasaran Dan
Selain kesamaan bahasa, kekuatan perantara atau mediasi juga menjadi faktor penentu keberhasilan komunikasi. ${ }^{3}$ Papan petunjuk arah tergolong sebagai media komunikasi visual. Media visual ialah media publitas yang dipergunakan untuk mengadakan hubungan dengan publik, yang dapat ditangkap dengan indera mata. ${ }^{4}$ Bentuk media komunikasi visual biasanya dapat menarik khalayak dibandingkan dengan apabila disampaikan secara verbal. ${ }^{5}$

Sebagai media komunikasi visual, papan-papan informasi dan petunjuk arah di tempat-tempat wisata mulai banyak digunakan, karena keberadaannya mampu menginformasikan petunjuk arah-arah lokasi kepada para wisatawan. Ia juga mempunyai karisma yang kuat untuk mengajak wisatawan mengunjungi tempat atau wahana-wahana yang disediakan di tempat wisata.

Salah satu kota di Indonesia yang banyak dikunjungi oleh wisatawan ialah kota Bogor, salah satu tempat wisatanya ialah wanawisata Curug 7 Cilember. Curug 7 Cilember terkenal sebagai objek wisata yang banyak diminati baik oleh wisatawan nusantara maupun mancanegara. Dalam lima tahun terakhir, pengunjung Curug 7 Cilember terus mengalami peningkatan. Pada tahun 2012 jumlah pengunjung 218.411 wisatawan, tahun 2013 jumlah pengunjung meningkat menjadi 234.287 wisatawan, tahun 2014 mencapai 254.496 wisatawan, dan pada tahun 2015 jumlah pengunjung meningkat secara drastis, yakni 323.163 wisatawan, adapun pada tahun 2016 jumlah

Brand Destinasi. (Jakarta: Aditya Andrebina Agung, 2015), 49.

${ }^{4}$ H.A.W Widjaja, Komunikasi: Komunikasi Dan Hubungan Masyarakat. (Jakarta: Bumi Aksara, 2008), 80.

5 Pawit M Yusuf, Komunikasi Instruksional: Teori Dan Praktek. (Jakarta: Bumi Aksara, n.d.), 222. 
pengunjung mencapai $\quad 336.127$ wisatawan. $^{6}$

Dilihat dari dunia bisnis kepariwisataan kini bisnis pariwisata menempati posisi unggul dalam pendapatan negara Indonesia. Maka dengan demikian, bahasa Arab akan berkembang pesat jika dikaitkan dengan dunia pariwisata, khususnya wisata Indonesia yang belum ramah dengan penggunaan bahasa Arab. Bahasa Arab jauh lebih sedikit diterapkan pada bisnisbisnis pariwisata Indonesia dibandingkan dengan bahasa Inggris.

\section{B. Pembahasan}

\section{Metode Penerjemahan Komunikatif}

Ketika menerjemahkan suatu kata atau teks, artinya penerjemah menjelaskan suatu bahasa ke dalam bahasa lain. ${ }^{7}$ Hakikatnya, penerjemahan bukan hanya proses penggantian teks dari satu bahasa ke dalam bahasa lain, melainkan juga proses menyalin atau memindahkan makna, supaya pesannya dapat dipahami oleh orang lain yang tidak mampu memahami bahasa asal atau aslinya. ${ }^{8}$ Penerjemahan dipandang sebagai sebuah proses komunikasi. Dalam proses ini terjadi transfer informasi; dari informasi yang diekspresikan dalam satu bahasa ditransfer menjadi informasi dalam bahasa lain. ${ }^{9}$

Metode adalah cara teratur yang digunakan untuk melaksanakan suatu pekerjaan agar tercapai sesuai dengan

\footnotetext{
6 Pengelola Curug 7 Cilember. Okupansi Pengunjung (Microsoft Office). (Bogor: Lembaga Curug 7 Cilember, 2017).

${ }^{7}$ Izudin Muhammad Najib, Usus Al-Tarjamah; Translation. (Cairo: Maktabah Ibn Sina, 2001), 7.

8 Suma Muhammad Amin, Ulumul Qur'an. (Jakarta: Raja Grafindo Persada, 2013).

9 Eko Setyo. Humanika, Mesin Penerjemah: Suatu Tinjauan Linguistik. (Yogayakarta, Indonesia: Gadjah Mada University, 2002).
}

yang dikehendaki; cara kerja yang bersistem untuk memudahkan pelaksanaan suatu kegiatan guna mencapai tujuan yang ditentukan. ${ }^{10}$ Metode adalah sebuah teknik yang biasa digunakan oleh seseorang.

Adapun metode penerjemahan ialah teknik khusus yang dipergunakan oleh penerjemah saat hendak memutuskan menerjemahkan suatu kata atau teks. ${ }^{11}$ Metode penerjemahan berarti cara menerjemahkan yang digunakan oleh penerjemah dalam mengungkapkan makna bahasa sumber secara keseluruhan ke dalam bahasa sasaran. ${ }^{12}$ Dengan menggunakan metode penerjemahan, hasil terjemahan akan mudah dipahami oleh pembaca atau komunikan.

Ketika menerjemahkan, boleh jadi penerjemah menggunakan lebih dari satu metode. Hanya saja, biasanya terdapat satu metode yang dominan yang menjadi kecenderungan penerjemah dalam proses menerjemahkan. Pada penerjemahan yang peneliti lakukan metode dominan yang digunakan ialah metode komunikatif, yang merupakan salah satu metode yang berorientasi pada keterbacaan bahasa sasaran.

Menurut Newmark penerjemahan komunikatif berupaya untuk menerjemahkan makna kontekstual dalam teks bahasa sumber, baik aspek bahasa maupun aspek isi. ${ }^{13}$ Sehinngga dengan demikian, isi dan makna pada bahasa sumber dapat diterima dan

${ }^{10}$ Tim Penyusun Kamus Pusat Bahasa, Kamus Bahasa Indonesia. (Pusat Bahasa, n.d.).

11 Moch. Syarif. Hidayatullah, Seluk-Beluk Penerjemahan Arab-Indonesia Kontemporer: Dasar, Teori, Dan Masalah. (Tangerang Selatan: AlKitabah, 2014), 57.

12 Syihabuddin, Penerjemahan Arab-Indonesia Teori Dan Praktek. (Bandung: Humaniora, 2002).

13 Peter Newmark, Approach to Translation. (Oxford: Pergamon Press, 1981). 
dipahami oleh pembaca. $^{14}$ Metode penerjemahan komunikatif dilakukan dengan mempertimbangkan tingkat kematangan berbahasa pembaca dan pesan yang disampaikan.

Saat menerjemahkan dengan metode ini, seorang penerjemah mereproduksi makna kontekstual yang sedemikian rupa. ${ }^{15}$ Pesan yang diterima dan dipahami oleh pembaca teks bahasa sasaran menjadi aspek terpenting yang diperhatikan oleh penerjemah. Penerjemahan komunikatif adalah penerjemahan yang menitikberatkan efek yang ditimbulkan oleh suatu terjemahan pada pembaca atau pendengar. ${ }^{16}$

Penerjemahan dengan metode komunikatif dapat dikatakan yang paling mudah dipahami pembaca karena penerjemah menafsirkan teks yang diterjemahkan. Penerjemahan komunikatif juga sangat memperhatikan keefektifan bahasa terjemahan. ${ }^{17}$ Oleh karena itu, dengan menggunakan metode penerjemahan komunikatif, biasanya pesan bisa langsung dapat dimengerti oleh pembaca atau pendengar.

$$
\text { Metode penerjemahan }
$$

komunikatif sering dipakai dalam menerjemahkan teks informatif dan teks vokatif. ${ }^{18}$ Kata atau teks yang terdapat dalam papan petunjuk arah dapat tergolong sebagai teks informatif dan juga vokatif. Maka penerjemahan papan petunjuk arah dengan metode

14 Syihabuddin, Penerjemahan Arab-Indonesia Teori Dan Praktek., 73.

15 Hidayatullah, Seluk-Beluk Penerjemahan Arab-Indonesia Kontemporer: Dasar, Teori, Dan Masalah., 63.

${ }^{16}$ Humanika, Mesin Penerjemah: Suatu Tinjauan Linguistik., 21.

17 M. Rudolf Nababan, Teori Menerjemah Bahasa Inggris. (Pustaka Pelajar, 2008).

${ }^{18}$ Frans Sayogie, Penerjemahan Bahasa Inggris Ke Dalam Bahasa Indonesia. (Lembaga Penelitian UIN Syarif Hidayatullah, 2008), 90. komunikatif ialah penyampaian informasi petunjuk arah serta informasi lainnya dari bahasa sumber ke bahasa sasaran sebagai proses pengantar komunikasi kepada komunikan. Hasil terjemahan papan petunjuk arah dengan menggunakan metode penerjemahan komunikatif, akan melahirkan komunikasi yang efektif, yakni terjemahan langsung dapat dimengerti oleh pembaca.

\section{Media Komunikasi Visual}

Komunikasi manusia bersifat multimode dan multimedia. ${ }^{19}$ Media adalah sarana untuk menyampaikan pesan atau informasi kepada publik dengan menggunakan berbagai unsur komunikasi grafis seperti teks, gambar, atau foto. ${ }^{20}$ McLuhan menyebut bahwa media adalah perluasan alat indra manusia. Dengan kata lain, kehadiran media dalam berkomunikasi tidak lain dari upaya untuk melakukan perpanjangan dari telinga dan mata. ${ }^{21}$

Salah satu media yang digunakan dalam berkomunikasi ialah media visual. Beberapa pakar psikolog memandang bahwa dalam komunikasi antarmanusia media yang paling dominan digunakan adalah pancaindra manusia, seperti melihat dan mendengar. Media visual termasuk sebagai media yang dominan. Media visual adalah media publitas yang dipergunakan untuk mengadakan hubungan dengan publik, yang dapat ditangkap dengan indera mata. ${ }^{22}$

19 Danesi Marcel, Pesan,Tanda, Dan Makna: Buku Teks Dasar Mengenai Semiotika Dan Teori Komunikasi. (Yogayakarta, Indonesia: Jalasutra, 2010), 398.

20 Maimunah, Lusyani Sunarya, dkk, "Media Company Profile sebagai Sarana Penunjang Informasi dan Promosi." (Tangerang: Jurnal CCIT, 2012).

${ }^{21}$ Anwar Arifin, Komunikasi Politik: Paradigma - Teori-Aplikasi - Strategi Komunikasi Politik Indonesia. (Balai Pustaka, 2003).

${ }^{22}$ Widjaja, Komunikasi: Komunikasi Dan 
Media visual mencirikan bahasa isyarat, tulisan, dan representasi visual seperti menggambar, memahat, dan sebagainya. Dalam komunikasi visual komunikan menggunakan bahasa visual, di mana unsur dasar bahasa visual (yang menjadi kekuatan utama dalam penyampaian pesan) adalah segala sesuatu yang dapat dilihat dan dapat dipakai untuk menyampaikan arti, makna, atau pesan. ${ }^{23}$ Pesan komunikasi visual pada hubungan komunikator dan komunikan sepenuhnya tidak ditentukan situasi, melainkan bagaimana komunikan menafsirkan sebuah teks atau gambar. ${ }^{24}$

Bentuk komunikasi visual biasanya dapat menarik khalayak dibandingkan dengan apabila hanya disampaikan dengan cara verbal. Seperti yang dikatakan oleh Dwyer bahwa pada umumnya orang mampu mengingat $10 \%$ dari apa yang dibacanya; $20 \%$ dari apa yang didengarnya; 30\% dari apa yang dilihatnya; dan 50\% dari apa yang dilihat dan didengarnya. ${ }^{25}$

Bidang komunikasi visual adalah bidang desain grafis yang sangat menantang di bidang industri pariwisata. Komunikasi visual dalam bidang pariwisata kini sudah digunakan untuk pemasaran pariwisata, baik untuk mengkomunikasikan aksesibilitas, destinasi wisata, sumber daya kepada wisatawan serta untuk menunjang ketertarikan wisatawan pada sarana dan prasanarana yang disediakan oleh

\footnotetext{
Hubungan Masyarakat., 80.

${ }^{23}$ Adi. Kusrianto, Pengantar Desain Komunikasi Visual. (Yogayakarta, Indonesia: Penerbit ANDI, n.d.), 10.

24 Bungin, Komunikasi Pariwisata (Tourism Communication): Pemasaran Dan Brand Destinasi., 251.

${ }^{25}$ Yusuf, Komunikasi Instruksional: Teori Dan Praktek., 222.

26 Bungin, Komunikasi Pariwisata (Tourism Communication): Pemasaran Dan Brand Destinasi., 96.
}

lembaga pariwisata. Oleh karena itu, bidang ini akan selalu berkembang di masa depan di mana kajiannya diarahkan kepada komunikasi enterpreneurship, kreativitas, seni, dan kebebasan berkreasi. $^{26}$

\section{Pariwisata}

Pariwisata sebagai suatu istilah mulai berkembang dan populer digunakan di Indonesia setelah Musyawarah Nasional Tourisme II di Tretes, Jawa Timur pada tanggal 12-14 Juni $1958 .{ }^{27}$ Sebagai salah satu bentuk aktivitas masyarakat, pariwisata berkembang pesat dalam sejarah kehidupan manusia sejak pertengahan abad lalu. ${ }^{28}$

Menurut Mathiese dan Wall, wisata adalah kegiatan bepergian daridan ke tempat tujuan lain di luar tempat tinggalnya. ${ }^{29}$ Sementara itu pada UU No. 10 tahun 2009 menyebutkan bahwa yang dimaksud dengan wisata adalah kegiatan perjalanan yang dilakukan seseorang atau sekelompok orang dengan mengunjungi tempat tertentu untuk tujuan rekreasi, pengembangan pribadi, atau mempelajari keunikan daya tarik wisata yang dikunjungi, dalam jangka waktu sementara. Istilah pariwisata berasal dari dilaksanakanya kegiatan wisata yaitu suatu aktivitas perubahan tempat tinggal sementara seseorang, ke luar tempat tinggalnya sehari-hari bersifat sementara dengan suatu alasan apapun kecuali

27 Ida Bagus Wyasa Putra and Putu Sudharma Sumadi, Hukum Bisnis Pariwisata. (Bandung: Refika Aditama, 2003), 153.

${ }^{28}$ I Gde Pitana and I Ketut Surya Diarta, Ilmu Pariwisata. (Yogayakarta, Indonesia: Penerbit ANDI, 2009), 10.

29 Fandeli. Chafid, Dasar-Dasar Manajemen Kepariwisatan Alam. (Yogayakarta, Indonesia: Liberty Offset, 2001), 36. 
melakukan kegiatan yang bisa menghasilkan upah atau gaji. ${ }^{30}$

Dari beberapa pengertian mengenai pariwisata, maka dapat disimpulkan bahwa pariwisata adalah perjalanan ke tempat tujuan lain di luar tempat tinggal untuk tujuan tertentu. Sebenarnya, perjalanan wisata merupakan kegiatan manusia yang memiliki kebutuhan, keinginan, serta harapan yang bermacam-macam yang berbeda satu orang dengan orang lainnya. ${ }^{31}$

\section{Bisnis Pariwisata dan Bahasa Arab}

Kegiatan kepariwisataan merupakan kegiatan yang bersifat sistem, memiliki ruang lingkup, komponen, dan proses tersendiri. Merupakan sistem perdagangan yang bersifat khusus, berobyek jasa, dan mendapat dukungan dari sistem lainnya, seperti sistem sosial, budaya, lingkungan hidup, sistem religi, dan sistem-sistem lainnya. ${ }^{32}$

Setiap perjalanan wisata melibatkan wisatawan, penyedia jasa transportasi, penyedia jasa akomodasi, jasa atraksi. Antara satu dengan yang lain memiliki hubungan fungsional dan berdasarkan hubungan itulah kegiatan perjalanan wisata dapat berlangsung. Hubungan-hubungan tersebut dapat menjadi sumber pajak dan pendapatan negara, sehingga banyak negara yang memanfaatkan industri pariwisata untuk meningkatkan pendapatan negaranya.

Pariwisata dewasa ini menjadi sebuah mega bisnis. Sebab, jutaan orang mengeluarkan ribuan rupiah ataupun

30 A.J Muljadi and Andri Warman, Kepariwisataan Dan Perjalanan (Jakarta: Rajawali, n.d.).

${ }^{31}$ Oka A Yoeti, Ekonomi Pariwisata: Introduksi, Informasi, Dan Implementasi. (Kompas Media Nusantara, 2008). dollar untuk menghabiskan waktu luang untuk memuaskan diri dengan cara berwisata. Bisnis pariwisata adalah aspek kegiatan kepariwisataan yang berorientasi pada penyediaan jasa pariwisata yang dibutuhkan wisatawan. ${ }^{33}$ Menurut Pasal 1 angka 5 UU No.9 Tahun 1990, usaha pariwisata diartikan sebagai "kegiatan yang bertujuan menyelenggarakan jasa pariwisata atau menyediakan atau mengusahakan obyek dan daya tarik wisata, usaha sarana pariwisata dan usaha lain yang terkait di bidang tersebut." 34

Obyek dan daya tarik wisata merupakan dasar bagi kepariwisataan. Daya tarik wisata adalah segala sesuatu yang memiliki keunikan, keindahan, dan nilai yang berupa keanekaragaman kekayaan alam, budaya dan hasil buatan manusia yang menjadi sasaran atau tujuan kunjungan wisata. ${ }^{35}$ Daya tarik wisata akan memberikan kepuasaan kepada wisatawan, oleh karena itu daya tarik wisata juga dilengkapi dengan sarana prasarana yang dibutuhkan wisatawan. Di antara pelengkap sarana prasarana wisata, yaitu:

a. akomodasi,

b. akses,

c. fasilitas,

d. transportasi,

e. catering service,

f. aktivitas rekreasi,

g. pembelanjaan (penyediaan kios),

h. komunikasi,

i. kesehatan,

j. keamanan,

k. kebersihan,

\footnotetext{
32 Putra and Putu Sudharma Sumadi, Hukum Bisnis Pariwisata., 17.

${ }^{33}$ Putra and Putu Sudharma Sumadi, 17.

${ }^{34}$ Putra and Putu Sudharma Sumadi, 153.

35 I Gusti Bagus Arjana, Geografi Pariwisata Dan Ekonomi Kreatif. (Jakarta: RajaGrafindo Persada, 2016).
} 
1. sarana ibadah,

m. sarana pendidikan, dan

n. sarana olahraga.

Kelengkapan sarana dan prasarana di tempat wisata (khususnya wisata di Indonesia) akan lebih efektif jika disertai dengan penyajian informasiinformasi dengan menggunakan lebih dari satu bahasa. Hal ini mempertimbangkan bahwa wisatawan yang datang bukan hanya wisatawan nusantara saja, melainkan juga wisatawan mancanegara baik dari negara-negara Barat atau Timur Tengah. Oleh karena itu, selain penggunaan bahasa Indonesia atau Inggris, bahasa Arab juga perlu ditampilkan di industri pariwisata Indonesia. Penggunaan bahasa Arab di industri pariwisata dilakukan salah satunya untuk kepentingan wisatawan yang komunikasinya menggunakan bahasa Arab. Selain itu, penggunaan bahasa Arab juga mesti dilestarikan dan dikembangkan di Indonesia karena bahasa Arab merupakan bahasa Internasional. $^{36}$

\section{Pengembangan Pariwisata dan Bahasa Arab}

Sesuai Undang-Undang No. 9 tahun 1990 menyebutkan bahwa tujuan pengembangan pariwisata adalah:

a. Memperkenalkan, mendayagunakan, melestarikan, dan meningkatkan mutu dan daya tarik wisata.

b. Memupuk rasa cinta tanah air dan meningkatkan persahabatan antarbangsa.

c. Memperluas dan meratakan kesempatan berusaha dan lapangan kerja.

36 "Ahmad Makki Hasan. 7 Alasan Belajar Bahasa Arab, Diakses Dari, Pada Tanggal 7 Desember 2017, Pukul 08.04 WIB.," n.d., https://www.kompasiana.com/amp/ahmadmakki d. Meningkatkan pendapatan nasional dalam rangka meningkatkan kesejahteraan dan kemakmuran rakyat.

e. Mendorong pendayagunaan produk nasional.

Sektor pariwisata selain mampu menjadi sektor andalan dalam usaha meningkatkan perolehan devisa negara, juga mampu mengentaskan kemiskinan. Pariwisata memiliki andil dan memberikan kontribusi besar dalam meningkatkan kesejahteraan rakyat kecil di mana proyek pariwisata dikembangkan. Keterlibatan langsung masyarakat yang berpendapatan rendah dalam program-program pengembangan pariwisata melalui pemanfaatan hasil kerajinan tangan, hasil pertanian, peternakan, perkebunan, produk hasil seni dan budaya tradisional serta pengembangan desa wisata sangat membantu usaha peningkatan kemiskinan itu. ${ }^{37}$

Wisatawan yang datang ke daerah tempat wisata tentu akan membeli produk masyarakat. Dampak pengeluaran wisatawan terhadap perekonomian inilah yang dapat membantu mengentaskan kemiskinan di Indonesia. Selain mengentaskan kemiskinan, mengembangkan pariwisata sebagai suatu industri akan terjadi peningkatan dalam: kesempatan berusaha, kesempatan kerja, penerimaan pajak, pendapatan nasional, dan sekaligus akan memperkuat posisi neraca pembayaran.

Tujuan-tujuan pengembangan pariwisata tersebut dapat membuka peluang agar bahasa Arab juga dapat dikembangkan di Indonesia. Salah satu caranya ialah dengan mengaitkan bahasa Arab di bidang industri pariwisata

hasan/5998312d86f75b210e2ae452/7-alasanbelajar-bahasa-arab.

37 Yoeti, Ekonomi Pariwisata: Introduksi, Informasi, Dan Implementasi., 18. 
Indonesia. Seiring berkembangnya industri pariwisata dan melesatnya para wisatawan yang datang ke tempattempat wisata di Indonesia, akan membuat wisatawan ramah dengan tampilan informasi berbahasa Arab.

\section{Wisata Curug Cilember}

Curug Cilember terletak di Desa Megamendung, Kecamatan Megamendung, Kabupaten Bogor, Jawa Barat. Pengelolaan Curug 7 Cilember dimulai pada tahun 1990 yang masuk wilayah kerja RPH (Resort Pemangkuan Hutan) Cipayung, BKPH (Badan Kesatuan Pemangkuan Hutan) Bogor, KPH (Kesatuan Pemangkuan Hutan) Bogor dan dibuka untuk umum. ${ }^{38}$ Pada tahun 1997, Wana Wisata Curug Cilember ditetapkan sebagai kawasan wanawisata andalan Perum Perhutani Unit III Jawa Barat. Pada tahun 2005, dilakukan pelimpahan pengelolaan Curug Cilember dari KPH Bogor ke Kesatuan Bisnis Mandiri Wisata Benih dan Usaha Lain (KBM WBU). ${ }^{39}$

Wana Wisata Curug Cilember merupakan salah satu dari dua potensi wisata yang berada di Cluster Bogor bersama Wana Wisata Curug Panjang. Curug Cilember memiliki destinasi wisata menarik sehingga banyak dikunjungi wisatawan domestik maupun wisatawan mancanegara. Destinasi wisata berupa air terjun dan penangkaran kupu-kupu di Curug Cilember menjadi mesin penghasil pendapatan wisata KBM Ecoturism kedua setelah wisata Kawah Putih. ${ }^{40}$

38 Pengelola Curug 7 Cilember. Okupansi Pengunjung (Microsoft Office).

39 "KBM WBU (Kesatuan Bisnis Mandiri Wisata Benih Dan Usaha Lain) Berubah Nama Menjadi KBM AEJ (Kesatuan Bisnis Mandiri Agroforestry, Ekowisata \& Jasa Lingkungan) Pada Tahun 2010. Dan Pada Tahun 2012, KBM AEJ Berubah Nama Menjadi KBM JLPL

\section{Wisatawan Timur Tengah dan Curug Cilember}

Salah satu hal istimewa yang dimiliki Curug Cilember adalah jumlah kunjungan wisatawan mancanegara yang cukup tinggi. Pada setiap tahunnya, sekitar 30\% dari jumlah pengunjung adalah wisatawan mancanegara. Wisatawan mancanegara di Curug Cilember didominasi oleh wisatawan asal Timur Tengah seperti Saudi, Bharain, Oman, Libanon dan Yaman (menurut sumber data Kec. Cisarua). ${ }^{41}$

Menurut data dari kecamatan Cisarua, para wisatawan Timur Tengah cenderung lebih suka kawasan wisata yang menyuguhkan suasana alam yang sejuk dan asri, yang memiliki potensi wisata seperti hutan, air terjun, sungai dan danau. ${ }^{42}$ Oleh sebab itu, kawasan puncak, salah satunya wisata Curug Cilember menjadi destinasi favorit wisatawan asal Timur Tengah untuk berwisata.

Wisatawan-wisatawan Timur Tengah tentunya memiliki kebutuhan untuk berkomunikasi ketika melakukan kegiatan wisata. Wisatawan yang datang ke Curug Cilember memerlukan pemahaman mengenai tempat yang dikunjunginya, baik memahami informasi yang ada maupun memahami hal-hal lain yang disajikan oleh pihak Curug Cilember. Pemahaman tersebut didapatkan ketika wisatawan dapat menjalin komunikasi yang efektif dengan pihak pengelola tempat wisata. Salah satu hal yang menjadi perhatian dalam berkomunikasi secara efektif ialah kesamaan bahasa. ${ }^{43}$ Terkait kesamaan bahasa, Curug Cilember belum totalitas

(Kesatuan Bisnis Mandiri Jasa Lingkungan \& Produk Lainnya)," n.d.

40 Trisna. Mulyana, Kajian Singkat Cilember. (Bogor: Lembaga Curug 7 Cilember, 2017), 1.

${ }^{41}$ Mulyana, 6.

${ }^{42}$ Mulyana, 7.

43 Sihabudin, Komunikasi Antarbudaya: Satu Perspektif Multidimensi., 88. 
dalam menyediakan informasi-informasi dengan bahasa Arab (bahasa yang mayoritas dimengerti oleh wisatawan Timur Tengah). Oleh karena itu, terjemahan dari bahasa Indonesia ke dalam bahasa Arab sangat diperlukan di Curug Cilember untuk menyampaikan pemahaman informasi yang tersedia kepada wisatawan Timur Tengah.

\section{Papan Informasi dan Petunjuk Arah di Curug Cilember}

Papan informasi dan petunjuk arah merupakan media komunikasi yang bersifat linear. Komunikasi linear maksudnya hanya terjadi satu arah, tanpa umpan balik terhadap pesan yang disampaikan. Pada proses linear, komunikator (penyampai pesan) berupaya semaksimal mungkin agar komunikasi berjalan efektif. ${ }^{44}$

Papan petunjuk arah yang bersifat linear tentu harus disajikan seefektif mungkin, salah satu caranya ialah dengan menampilkan papan tersebut dengan dua bahasa atau lebih. Sehingga wisatawan yang tidak mengerti bahasa Indonesia, ${ }^{45}$ dapat memahami pesan yang disampaikan pada papan tersebut dalam bahasa Arab atau Inggris. Akan tetapi, melihat dari data wisatawan yang datang ke Curug Cilember dominan berasal dari Timur Tengah, maka bahasa Arab lah yang dirasa lebih efektif untuk ditampilkan pada papan-papan tersebut.

Wana wiata Curug Cilember sejauh ini sudah melakukan penyajian papan dengan dua bahasa. Akan tetapi, hanya terdapat tiga papan yang dilengkapi dengan bahasa Arab. ${ }^{46}$ Padahal, minat wisatawan untuk berkunjung ke Curug Cilember cukup

\footnotetext{
${ }^{44}$ Effendy, Ilmu, Teori Dan Filsafat Komunikasi. Bandung, 38.

45 "Papan Informasi Dan Petunjuk Arah Yang Berada Di Curug Cilember Saat Ini Hanya Disajikan Dengan Satu Bahasa, Yakni Bahasa Indonesia.," n.d.
}

banyak, terutama wisatawan Timur Tengah. ${ }^{47}$ Selain itu, papan informasi dan petunjuk arah merupakan sarana prasarana yang juga menjadi daya tarik wisata sehingga seharusnya disajikan sesuai dengan kebutuhan wisatawan.

Adapun tiga papan yang sudah disajikan dengan bahasa Indonesia dan Arab yaitu:
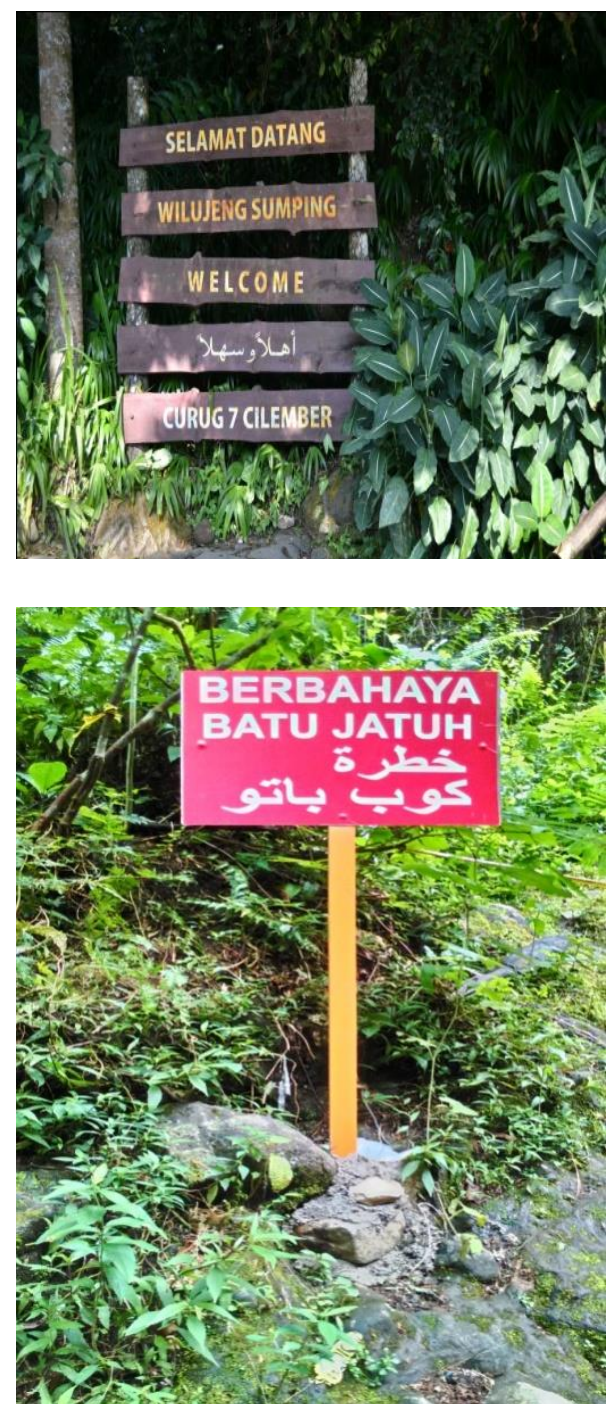


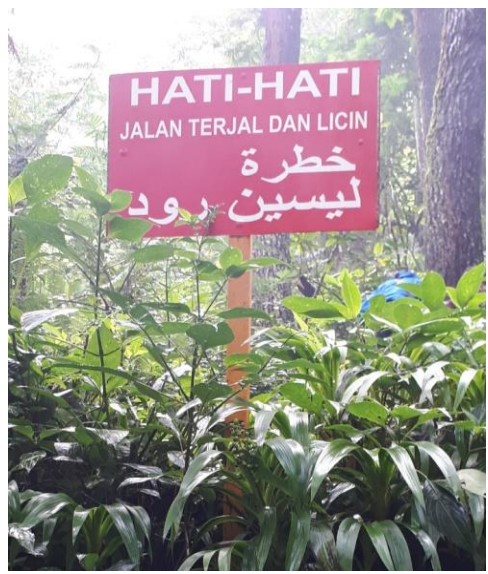

Dari ke-3 papan tersebut yang menggunakan bahasa Arab fushah hanya terdapat pada papan no.1. Hal ini juga menjadi hal yang perlu diperhatikan oleh pihak pengelola Pariwisata, khususnya Dinas Pariwisata kota Bogor. Sebab, penyajian bahasa Arab fushah lebih diperlukan supaya lebih mudah dipahami baik oleh wisatawan nusantara (yang mengerti bahasa Arab), maupun oleh wistawan mancanegara seperti Saudi, Bharain, Oman, Libanon dan Yaman.

Berdasarkan alasan-alasan di atas, maka peneliti melakukan penerjemahan papan-papan informasi dan petunjuk arah yang berada di Curug 7 Cilember ke dalam bahasa Arab. Penerjemahan yang dilakukan menggunakan metode komunikatif, supaya pesan yang terdapat pada papanpapan tersebut dapat langsung dipahami oleh para pembaca serta hasil terjemahan (bahasa Arab) tersebut menjadi bahasa yang berterima oleh pembaca. Metode komunikatif ini juga digunakan karena tujuan utama dari menerjemahkan papan-papan ini ialah agar komunikasi yang terjadi antara pihak Curug Cilember dan wisatawan berjalan secara efektif.

Berikut ini beberapa contoh hasil desain papan informasi dan petunjuk arah yang sudah dilengkapi dengan tampilan 2 bahasa (bahasa Indonesia dan bahasa Arab) beserta analisis terjemahan dengan metode komunikatif:

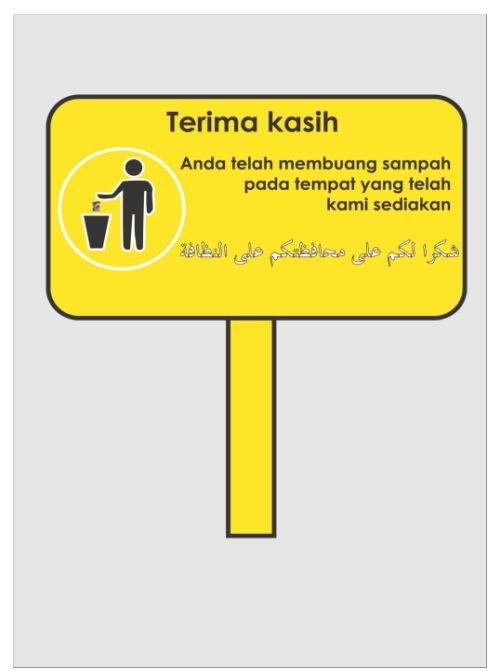

Penerjemah mengubah struktur dan gaya bahasa pada Bsa. Pada Bsu tertulis "Terimakasih, Anda telah membuang sampah pada tempat yang telah kami sediakan". Peneliti menerjemahkannya dengan مُحَافَظَنَكُمَ عَلَى شُُكُرًا لَكُم عَلَى النَََّفَة Terimakasih Anda telah menjaga kebersihan. Makna kalimat "Terimakasih, Anda telah membuang sampah pada tempat yang telah kami sediakan" adalah sebagai ucapan terimakasih kepada para wisatawan Curug 7 Cilember karena sudah menjaga kebersihan lokasi wisata. Sehingga, ketika diterjemahkan dengan مُافَظَتَكُمَ شُُكُرًا الَكُم عَلَى عَلَى النَََّافَة kalimat tersebut tidaklah berbeda.

Kata مُحافَظَّة bisa diganti dengan kata حفَاً yang dalam aplikasi luring kamus Al-Maaniy versi 1.1 sama-sama memiliki arti pemeliharaan, pengawetan, pelestarian, penjagaan, perawatan. Maka, ungkapan terimakasih untuk orang yang telah menjaga kebersihan juga bisa diterjemahkan dengan شُكُرَا لِلْحفَاظَ عَلى النَّظَََفَة. 
Ungkapan dengan kata حفَاظ juga lazim digunakan di Mesir. ${ }^{48}$

Penerjemahan kalimat ini tidak diterjemahkan secara kata per kata, melainkan dengan mengubahnya ke dalam ungkapan yang biasa digunakan pada kebudayaan Arab. Penerjemah mengubah gaya bahasa menjadi lebih ringkas dan lugas. Meskipun demikian, hasil terjemahan tetap mempertahankan makna yang terkandung dalam Bsu. Sebab penggunaan ungkapan

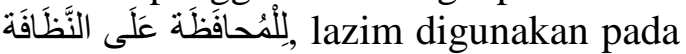
kebudayan Arab, seperti di Mesir, Uni Emirat Arab dan Turki. Beberapa artikel dan berita di kota-kota tersebut menggunakan kata مُحافَظَة عَلَى النَََّافَة.

Selain itu, penerjemah juga melakukan penelusuran Google gambar

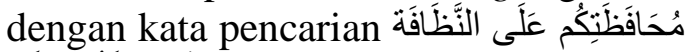
شُُكْرًا لَكُم عَلَى , untuk memastikan apakah ungkapan tersebut berlaku di kebudayaan Arab dan serta untuk mengetahui maknanya apakah menunjukkan maksud menjaga kebersihan lingkungan. Gambar yang muncul pada hasil penelusuran, yakni:

\section{Gambar 1: Gambar hasil}

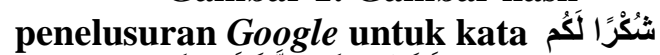

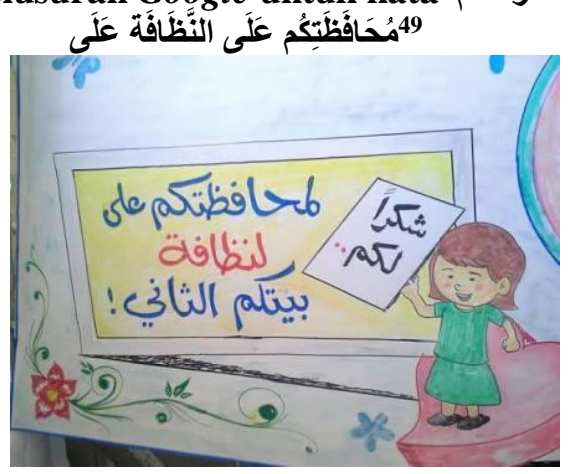

48 “Informasi Ini Didapat Dari Fatima El Zahraa, Yang Merupakan Anggota Himpunan Penerjemah Indonesia, Yakni Fatima El Zahraa, M.Pd.I Pada Acara Workshop Dan Pelatihan Bimbingan Karier Sebagai Penerjemah Pemula Bagi Mahasiswa, Ada Tanggal 2 November 2017," n.d.

49 “'Aplikasi Daring Pinterest. عبارات و رسومات النظافة Diakses Dari Https://Www.Pinterest.Co.Uk/Alabsyds/ Pada
Gambar ini menunjukkan bahwa kalimat شُكُر ا لكم على مُحافَظَنَكُمْ عَلَى النَّظَافَة lazim digunakan sebagai ungkapan dari ucapan terimakasih untuk orang yang telah menjaga kebersihan. Pada gambar tersebut juga menggunakan isim dhamir Sُ yang bermakna kalian atau bisa juga dimaknai dengan Anda.

Metode penerjemahan yang digunakan ialah metode yang berorientasi pada keterbacaan Bsa dengan prinsip komunikatif meskipun mengubah struktur dan gaya bahasa, tetapi dengan tetap menimbulkan makna yang sama dengan bahasa yang lebih ringkas dan lugas. Pada papanyang

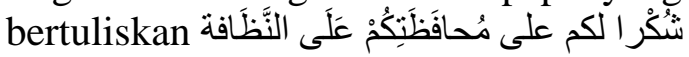
penerjemah menggunakan gambar seseorang yang sedang membuang sampah ke tempat sampah, sehingga menunjukkan sikap seseorang yang telah menjaga kebersihan lokasi tersebut. Gambar ini menjadi pelengkap pemahaman untuk komunikan dalam berkomunisai melalui media visual.

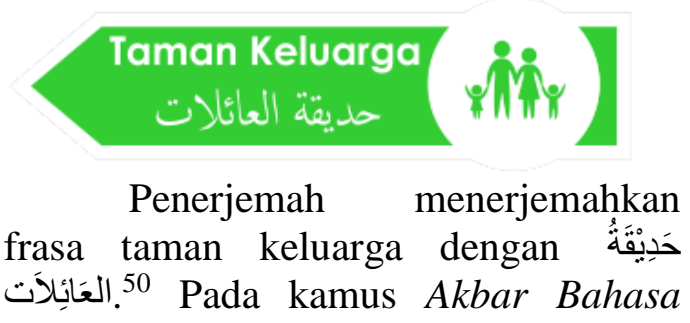

Tanggal 13 Februari 2018, Pukul 12.17 WIB.," n.d.

50 “'Selain Diterjemahkan Dengan العَائلاًت حَدِيْقَةُ

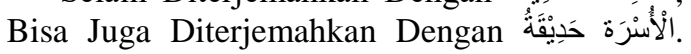
Kedua Kata Ini Lazim Digunakan Dalam Kebudayaan Arab, Karena Dalam Beberapa Berita Atau Artikel Terkait Tema 'Taman

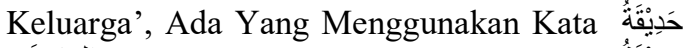
حَدِيقِقة

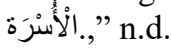


Arab (Indonesia-Arab), ${ }^{51}$ taman diterjemahkan dengan خَدِيْقَة

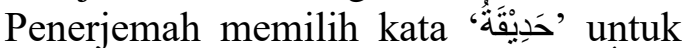
menerjemahkan taman, karena kata حَبْيََْة lebih umum dan lazim digunakan pada kebudayaan Arab. العَائِلاًت merupakan bentuk jamak dari عَائَلَّة Berbeda dengan kebudayaan di Indonesia yang lebih menyukai penggunaan struktur-struktur yang singkat, dalam kebudayaan Arab lebih banyak penggunaaan kata berbentuk jamak. Oleh karena itu, penerjemah menerjemahkan kata keluarga dengan bentuk jamak dalam Bsa (bahasa Arab). عَائََنَ artinya keluarga sesuai dengan kamus Wehr ArabicEnglish. ${ }^{52}$

Penerjemah juga melakukan penelusuran Google dan ditemukan beberapa berita yang menggunakan kata حَبِيْقَة العَائلاَتا

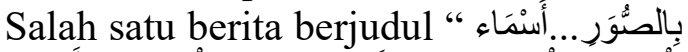

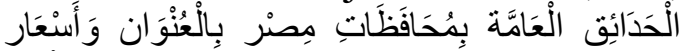
الثِتَّاكَرك beberapa istilah dan nama-nama taman

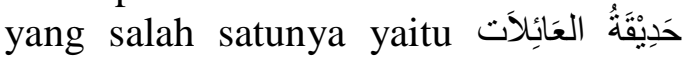
(taman keluarga). ${ }^{53}$

Metode penerjemahan yang digunakan adalah metode yang berorientasi pada keterbacaan $\mathrm{BSa}$ dengan prinsip komunikatif yang lebih mementingkan pemahaman dan kebudayaan para pembaca BSa. Pada papan petunjuk arah yang bertuliskan حَِيْقَةُ العَاِيْلاًت gambar sebuah keluarga, yakni ayah, ibu, dan anak yang saling bergandengan.

\footnotetext{
${ }^{51}$ A. Thoha Husein Almujahid dan A. Atho'illah Fathoni Alkhalil, Kamus Akbar Bahasa Arab (Indonesia-Arab). (Jakarta: Gema Insani, 2013), h. 1382

${ }^{52}$ Hans Wehr, ..Arabic-English Dictionary: The Hans Wehr Dictionary of Modern Written Arabic. (New York: Spoken Language Services, 1976).

53 "Shofa Zidan, العامة الحدائق أسماء..بالصور التذاكر وأسعار بالعنوان مصر بمحافظات الترات Dari

Https://Www.Google.Co.Id/Amp/s/Www.Nmisr
}

Gambar ini menjadi pelengkap pemahaman untuk komunikan dalam berkomunisai melalui media visual.

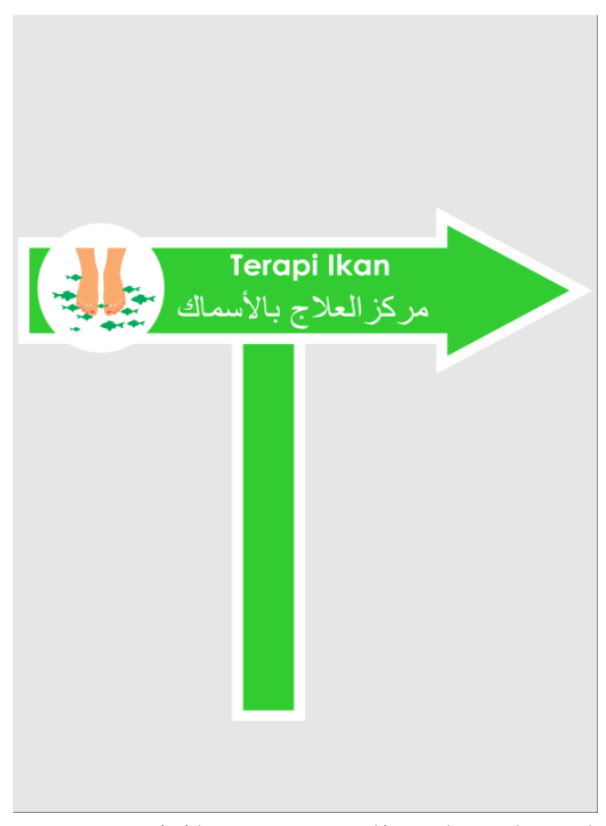

Terapi ikan yang dimaksud pada papan petunjuk arah menunjukkan sebuah tempat yang terdapat kolam berisi ikan-ikan kecil yang digunakan untuk terapi. Oleh karena itu, penerjemah menggunakan kata 54 كَرْكز yang bermakna pusat, fokus, posisi, pos, lokasi, tempat, kedudukan, markas. ${ }^{55}$ Kata مَرْكَ digunakan agar pembaca Bsa mengetahui bahwa pada papan petunjuk arah tersebut mengarahkan ke sebuah tempat terapi ikan.

Penerjemah menerjemahkan kata terapi dengan kata عِلاَج sesuai dengan kamus Akbar Bahasa Arab (IndonesiaArab). ${ }^{56}$ Begitu juga dalam kamus $A$

Com/Home/الحدائق-أسماءAmp, Pada Tanggal 20 Januari 2018, Pukul 17.00 WIB.," n.d.

54 “Informasi Ini Didapat Dari Hasil Wawancara Pada Tanggal 20 Januari 2018 Dengan Informan Yang Merupakan Pengguna Bahasa Arab (Native) Mesir, Yakni Mahmoud Mohammed Hosny Mohammed, Lc.," n.d.

${ }^{55}$ Aplikasi luring kamus Al-Maaniy versi 1.1

${ }^{56}$ A. Thoha Husein Almujahid dan A. Atho'illah Fathoni Alkhalil, Kamus Akbar Bahasa Arab (Indonesia-Arab), h. 1424 
Dictionary of Modern Written Arabic ${ }^{57}$ memaknai kata عِلاًج dengan medical treatment; remedy; cure; therapy. Kata عِلاًج lazim digunakan di kebudayaan Arab, karena istilah-istilah pengobatan dengan kata terapi seringkali diterjemahkan dengan عِلاَج, misalnya

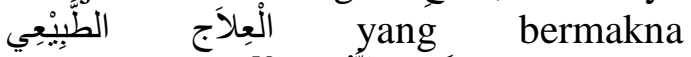
physiotherapi, ${ }^{58}$ bermakna hypnotherapi. ${ }^{59}$

Penerjemah menggunakan kata yang merupakan bentuk jamak dari سمَكك yang bermakna menggunakan. ${ }^{60}$ Huruf - digunakan sebagai pelengkap agar pembaca BSa lebih mudah memahami makna dari terapi ikan, yakni terapi yang menggunakan perantara atau media terapi berupa ikan-ikan kecil.

Metode penerjemahan yang digunakan adalah metode yang berorientasi pada keterbacaan $\mathrm{BSa}$ dengan prinsip komunikatif yang berusaha menciptakan pesan yang sama dari BSu ke dalam Bsa dan melakukan kesesuaian budaya Arab yakni dengan menggunakan kata yang lebih umum digunakan dalam BSa. Meskipun hasil terjemahan tampil dengan struktur yang lebih panjang (dalam Bsu terdapat 2 kata, sedangkan dalam Bsa menjadi 3 kata), tapi tidak menghilangkan pesan yang terkandung pada Bsu justru lebih memperjelas maksud dari BSu. Dengan hasil terjemahan seperti tersebut, maka pembaca tidak mengalami kesulitan dalam memahami pesan pada $\mathrm{BSu}$.

Pada papan petunjuk arah yang bertuliskan الْعِلاَج

57 Wehr, ..Arabic-English Dictionary: The Hans Wehr Dictionary of Modern Written Arabic., 633.

${ }^{58}$ Samir. Salih, Arabic-English Bilingual Visual Dictionary. (New York: Dorling Kindersley, 2009), 49.

${ }^{59}$ Salih, 55.

60 "Dalam Al-Mujam Al-Wasith Halaman 35, Huruf 'ب Memiliki Beberapa Makna. Diantaranya Menggunakan (Dengan); penerjemah juga menggunakan gambar kaki yang sedang digigit ikan-ikan kecil, gambar ini menunjuk ke arah tempat dimana wisatawan dapat melakukan terapi ikan. Hal ini dilakukan agar media komunikasi visual yang terpampang memberikan efek pemahaman bagi para komunikan.

Pada aplikasi luring kamus $A l$ Maaniy versi 1.1, kata toilet

diterjemahkan dengan beberapa kata di

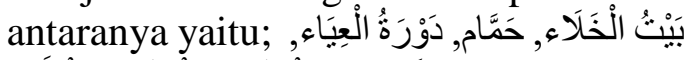

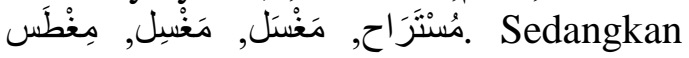
dalam kamus Modern Indonesia-Arab Al-Mufied, ${ }^{61}$ kata toilet diterjemahkan

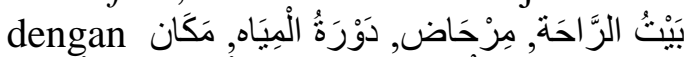

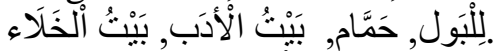

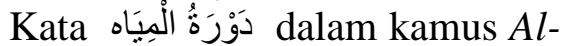
Mujam Al-Wasith, ${ }^{62}$ bermakna الْمِرَحَاض (WC/toilet, kamar mandi dan sebagainya). Adapun dalam kamus Oxford Arabic-English ${ }^{63}$

Menunjukkan Tempat (Di); Alasan (Karena); Bersama (Dengan).," n.d.

${ }^{61}$ Nur. Mufid, Kamus Modern Indonesia-Arab Al-Mufied. (Surabaya: Pustaka Progressif, 2010), 713.

${ }^{62}$ Syauqi Dhaif, .. Al-Mujam Al-Wasith. (Mesir: Maktabah Shurouq Ad-Dauliyyah, 2004), 303.

${ }^{63}$ Oxford Dictionaries, Oxford Arabic-English. (Oxford: Oxford University Press, 2014), h. 273, n.d. 
dimaknai dengan toilet, bathroom, restroom. Penerjemah menerjemahkan kata toilet dengan دَوْرَةُ الِِْيًَاه karena penerjemah menggunakan metode penerjemahan komununikatif yang sangat memperhatikan keefektifan bahasa sasaran. Ketika menerjemahkan dengan metode komunikatif, penerjemah harus dapat menerjemahkan suatu kata ke dalam Bsa sesuai dengan kebudayaan yang ada pada Bsa tersebut.

Kata دَوْرَةُ الْمِيَاه dinilai efektif karena dalam kebudayaan Arab, misalnya di Arab Saudi dan Mesir, toilet seringkali diterjemahkan dengan

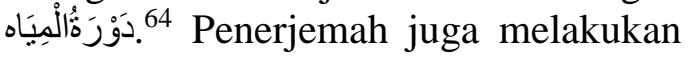
penelusuran Google dengan kata kunci untuk memastikan apakah kata tersebut lazim digunakan dalam kebudayaan Arab. Kemudian penerjemah menemukan sebuah artikel

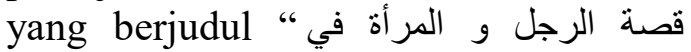
ملصقات دور ات المياه... احذر دخول الحمام الخداطئ (Cerita tentang pria dan wanita di poster toilet, Waspadalah saat memasuki kamar mandi yang salah di Arab saudi, Polandia, dan Lituania). ${ }^{65}$ Pada judul artikel tersebut terdapat frasa בَدْرَةُ الْمِيَّاه dan gambar yang muncul pada artikel tersebut yaitu;

Gambar 2: Gambar hasil pَوَْرَةُ الْمِيَاه

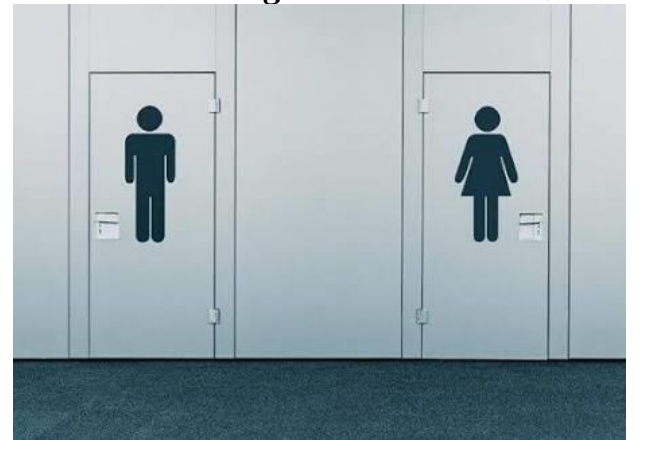

64 "Informasi Ini Didapat Pada Saat Dari Abdul Wadud Kasyful Anwar, M.A., Yang Berprofesi Sebagai Interpreter Kepresidenan RI.," n.d.

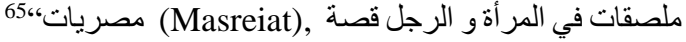

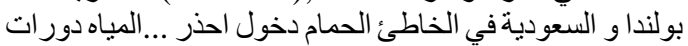

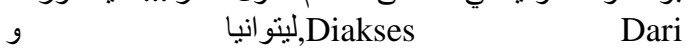

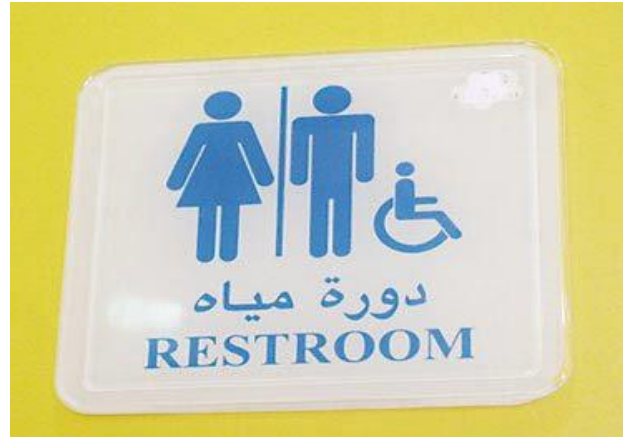

Gambar di atas menunjukkan bahwa toilet lazim diterjemahkan dengan دَوَرَةُ الْْيََاه dalam kebudayaan Arab, salah satunya di Arab Saudi. Dengan demikian, hasil terjemahan membuat pemahaman yang jelas bagi para wisatawan, khususnya wisatawan Arab. Metode penerjemahan yang digunakan adalah metode yang berorientasi pada keterbacaan BSa dengan prinsip komunikatif yang mementingkan pembaca $\mathrm{BSa}$ agar mudah memahami maksud dari BSu.Pada papan petunjuk arah yang bertuliskan دَوْرَةُ الِِْيَاه, penerjemah juga menggunakan sebuah gambar orang yang sedang duduk di WC. Hal ini dilakukan agar media komunikasi visual yang terpampang memberikan efek pemahaman yang jelas bagi para komunikan.

Kalimat di atas menggunakan kata 'mohon tidak'. Penerjemah menerjemahkan kata tersebut dengan menggunakan kata يُرْجَى yang bermakna diharapkan. ${ }^{66}$ Kata يُرْجَى menimbulkan efek yang lebih santun dibandingkan 


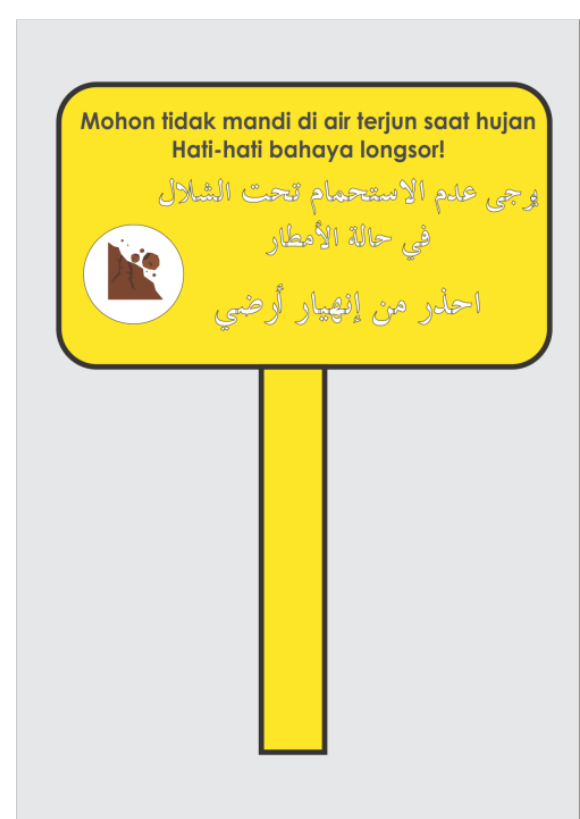

dengan menggunakan fi'il amr. ${ }^{67}$ Oleh karena itu, penerjemah menggunakan kata يُرْجَى agar tidak menghilangkan aspek santun.

Dalam kamus Al-Maaniy, 'mandi' diterjemahkan dengan - اسْنَحَمَّمَ Kata mandi tidak dapat diterjemahkan dengan kata سِبَاحَة yang dalam kamus Al-Wasith dimaknai dengan olahraga tubuh dengan cara terapung ${ }^{69}$ atau yang dikenal dengan berenang. Sebab, yang dilakukan wisatawan di bawah Curug bukan berenang, melainkan sekedar membasahi tubuh dan berendam di Curug. Oleh karena itu, pada kalimat ini penerjemah menggunakan kata الاسنتِحْمَاْ sebagai terjemahan dari mandi yang artinya adalah mandi. ${ }^{70}$

Maka, secara lengkap hasil terjemahan kalimat "Mohon tidak mandi di air terjun saat hujan!" ialah يُرْجَى عَدَمَ

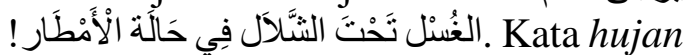
diterjemahkan dalam bentuk jamak. Hal ini karena dalam budaya Arab, lebih sering menggunakan kata-kata dalam bentuk jamak termasuk juga ketika

Didapat Dari Abdul Wadud Kasyful Anwar, Lc. M.A.," n.d.

67 Informasi ini didapat dari Abdul Wadud Kasyful Anwar, Lc. M.A
أَمْطَار menyebutkan kata hujan dengan bukan مطَر.

Metode penerjemahan yang digunakan ialah metode yang berorientasi pada keterbacaan $\mathrm{BSa}$ dengan menghasilkan terjemahan dengan kata-kata yang sesuai dengan gaya bahasa dalam budaya Arab serta berusaha tidak menghilangkan aspek kesantunan pada Bsu.

\section{Kesimpulan}

Papan informasi dan petunjuk arah merupakan media komunikasi visual. Oleh karena itu, setelah menerjemahkan papan petunjuk arah, penerjemah mengimplementasikannya ke dalam bentuk papan. Dengan melakukan hal tersebut, penerjemahan yang dilakukan memberikan dampak positif bagi banyak orang (khususnya wisatawan Arab) untuk mengetahui informasi yang disampaikan dari Bsu. Hal ini juga merupakan sebuah perkembangan sarana dan prasarana bagi tempat wisata tertentu, yang dalam penelitian ini fokus pada tempat wisata Curug 7 Cilember, Bogor.

Penerjemahan papan informasi
dan petunjuk arah sangat mempertimbangkan aspek budaya para pembaca bahasa sasaran supaya tidak ada kesalahpahaman dalam mengartikan informasi. Selain itu pemilihan diksi juga harus cocok dan sesuai dengan yang dimaksud oleh para pembaca bahasa sasaran. Oleh karena itu, beberapa kata dan kalimat tidak bisa diterjemahkan secara kata per kata, melainkan dengan metode komunikatif yang mempertimbangkan tingkat kematangan berbahasa pembaca dan pesan yang disampaikan.

\footnotetext{
${ }^{68}$ Aplikasi luring kamus Al-Maaniy versi 1.1

${ }^{69}$ Syauqi Dhaif, Al-Mujam Al-Wasith, h. 412

70 Ahmad Warson Munawwir, Al-Munawwir: Kamus Arab-Indonesia, h. 300
} 
Penerapan metode komunikatif dirasa lebih efektif digunakan untuk menerjemahkan papan informasi dan petunjuk arah. Hasil terjemahan metode komunikatif mampu menghantarkan pesan/informasi dari Bsu ke dalam Bsa dengan baik dan mudah dipahami. Hasil terjemahan metode komunikatif juga mempertimbangkan kelaziman penggunaan bahasa pada kebudayaan Bsa, sehingga pembaca Bsa tidak mengalami kesulitan dalam memahami makna yang ada pada Bsu. Dengan demikian, komunikasi antara pengelola wisata dengan wisatawan akan berlangsung secara efektif.

Dari uraian terdahulu, dapat disimpulkan bahwa setiap wisatawan yang datang tentu membutuhkan informasi dan petunjuk arah mengenai tempat yang dikunjunginya. Salah satu cara untuk mengetahui hal tersebut ialah melalui komunikasi yang baik dan efektif antara pengelola wisata dan wisatawan. Komunikasi yang dilakukan dapat berupa media komunikasi visual seperti pembuatan papan informasi dan petunjuk arah.

Tempat-tempat wisata lain (selain Curug 7 Cilember) juga memungkinkan untuk membuat media komunikasi visual berupa papan informasi dan petunjuk arah dengan 2 bahasa (Indonesia-Arab) atau lebih. Adanya media komunikasi visual dengan 2 bahasa ini juga menjadi sebuah pelengkap sarana dan pra sarana wisata yang dapat menjadi salah satu tingkat kepuasan wisatawan yang berkunjung.

\section{Daftar Pustaka}

"Ahmad Makki Hasan. 7 Alasan Belajar Bahasa Arab, Diakses Dari, Pada Tanggal 7 Desember 2017, Pukul $08.04 \quad$ WIB.," n.d. https://www.kompasiana.com/amp/ ahmadmakkihasan/5998312d86f75 b210e 2ae452/7-alasan-belajarbahasa-arab.

"Ahmad Warson Munawwir, Al-Munawwir: Kamus Arab-Indonesia, Cet. Ke-14. (Surabaya: Pustaka Progressif, 1997), h. 480 Informasi Ini Didapat Dari Abdul Wadud Kasyful Anwar, Lc. $\quad$ M.A.," n.d.

9 رسومات.Aplikasi Daring Pinterest لنظافة اعن ارشادية عبارات,

Diakses Dari Https://Www.Pinterest.Co.Uk/Alab syd s/ Pada Tanggal 13 Februari 2018, Pukul 12.17 WIB.," n.d.

Arifin, Anwar. Komunikasi Politik: Paradigma - Teori - Aplikasi Strategi Komunikasi Politik Indonesia. Jakarta: Balai Pustaka, 2003.

Arjana, I Gusti Bagus. Geografi Pariwisata Dan Ekonomi Kreatif. Jakarta: RajaGrafindo Persada, 2016.

Bungin, Burhan. Komunikasi Pariwisata (Tourism Communication): Pemasaran Dan Brand Destinasi. Jakarta: Aditya Andrebina Agung, 2015.

Chafid, Fandeli. Dasar-Dasar Manajemen Kepariwisatan Alam. Yogayakarta, Indonesia: Liberty Offset, 2001.

"Dalam Al-Mujam Al-Wasith Halaman 35, Huruf 'ب Memiliki Beberapa Makna. Diantaranya Menggunakan (Dengan); Menunjukkan Tempat (Di); Alasan (Karena); Bersama (Dengan).," n.d. 
Dhaif, Syauqi. Al-Mujam Al-Wasith. Mesir: Maktabah Shurouq Ad-Dauliyyah, 2004.

Effendy, Onong Uchjana. Ilmu, Teori Dan Filsafat Komunikasi. Bandung. Bandung: Citra Aditya Baktu, 2003.

Hidayatullah, Moch. Syarif. Seluk-Beluk Penerjemahan Arab-Indonesia Kontemporer: Dasar, Teori, Dan Masalah. Tangerang Selatan: AlKitabah, 2014.

Humanika, Eko Setyo. Mesin Penerjemah: Suatu Tinjauan Linguistik. Yogayakarta, Indonesia: Gadjah Mada University, 2002.

"Informasi Ini Didapat Dari Fatima El Zahraa, Yang Merupakan Anggota Himpunan Penerjemah Indonesia, Yakni Fatima El Zahraa, M.Pd.I Pada Acara Workshop Dan Pelatihan Bimbingan Karier Sebagai Penerjemah Pemula Bagi Mahasiswa, Ada Tanggal 2 November 2017 Di Teater Bustami Lt.05 Fakultas Adab Dan Humaniora, UIN Syarif Hidayatullah Jakarta.," n.d.

"Informasi Ini Didapat Dari Hasil Wawancara Pada Tanggal 20 Januari 2018 Dengan Informan Yang Merupakan Pengguna Bahasa Arab (Native) Mesir, Yakni Mahmoud Mohammed Hosny Mohammed, Lc.," n.d.

"Informasi Ini Didapat Pada Saat Dari Abdul Wadud Kasyful Anwar, M.A., Yang Berprofesi Sebagai Interpreter Kepresidenan RI.," n.d.

"KBM WBU (Kesatuan Bisnis Mandiri Wisata Benih Dan Usaha Lain) Berubah Nama Menjadi KBM AEJ
(Kesatuan Bisnis Mandiri Agroforestry, Ekowisata \& Jasa Lingkungan) Pada Tahun 2010. Dan Pada Tahun 2012, KBM AEJ Berubah Nama Menjadi KBM JLPL (Kesatuan Bisnis Mandiri Jasa Lingkungan \& Produk Lainnya)," n.d.

Kusrianto, Adi. Pengantar Desain Komunikasi Visual.

Yogayakarta, Indonesia: Penerbit ANDI, 2007.

Marcel, Danesi. Pesan,Tanda, Dan Makna: Buku Teks Dasar Mengenai Semiotika Dan Teori Komunikasi. Yogayakarta, Indonesia: Jalasutra, 2010.

Mufid, Nur. Kamus Modern Indonesia-Arab Al-Mufied. Surabaya: Pustaka Progressif, 2010.

Muljadi, A.J, and Andri Warman. Kepariwisataan Dan Perjalanan. Jakarta: Rajawali, 2016.

Mulyana, Trisna. Kajian Singkat Cilember. Bogor: Lembaga Curug 7 Cilember, 2017.

Nababan, M. Rudolf. Teori Menerjemah Bahasa Inggris. Yogayakarta, Indonesia: Pustaka Pelajar, 2008.

Najib, Izudin Muhammad. Usus AlTarjamah; Translation. Cairo: Maktabah Ibn Sina, 2001.

Newmark, Peter. Approach to Translation. Oxford: Pergamon Press, 1981. Oxford Dictionaries, Oxford Arabic-English. (Oxford: Oxford University Press, 2014), h. 273, n.d.

"Pada Setiap Tahunnya, Sekitar 30\% Dari Jumlah Pengunjung Adalah Wisatawan Mancanegara.," n.d. 
"Papan Informasi Dan Petunjuk Arah Yang Berada Di Curug Cilember Saat Ini Hanya Disajikan Dengan Satu Bahasa, Yakni Bahasa Indonesia.," n.d.

"Peneliti Melakukan Survei Terakhir Pada Tanggal 4 Maret 2018.," n.d.

Pengelola Curug 7 Cilember. Okupansi Pengunjung (Microsoft Office). Bogor: Lembaga Curug 7 Cilember, 2017.

Pitana, I Gde, and I Ketut Surya Diarta. Ilmu Pariwisata. Yogayakarta, I ndonesia: Penerbit ANDI, 2009.

Putra, Ida Bagus Wyasa, and Putu Sudharma Sumadi. Hukum Bisnis Pariwisata. Bandung: Refika Aditama, 2003.

Salih, Samir. Arabic-English Bilingual Visual Dictionary. New York: Dorling, 2009.

Sayogie, Frans. Penerjemahan Bahasa Inggris Ke Dalam Bahasa Indonesia. Jakarta: Lembaga Penelitian UIN Syarif Hidayatullah, 2008.

"Sحدِيْقَةُ Delain Diterjemahkan Dengan العَائلاًتا, Bisa Juga Diterjemahkan Dengan الأْسْرَة حَدِيْقَة الَْلَّْ. Kedua Kata Ini Lazim Digunakan Dalam Kebudayaan Arab, Karena Dalam Beberapa Berita Atau Artikel Terkait Tema 'Taman Keluarga', Ada Yang Menggunakan Kata Juga Ada Yang

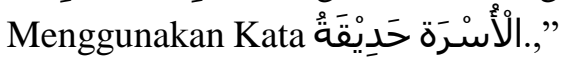
n.d.

"Shofa Zidan, الحدائق أسماء.بالصور بالعنوان مصر بمحافظات العامة

$$
\begin{aligned}
& \text { Https://Www.Google.Co.Id/Amp/s/ } \\
& \text { Www.Nmisr.Com/Home/أتذاكر وأسعار/Amp, Diakses Pada Tanggal 20 } \\
& \text { السمائق/Ami } \\
& \text { Januari 2018, Pukul 17.00 WIB.," } \\
& \text { n.d. }
\end{aligned}
$$

Sihabudin, Ahmad. Komunikasi Antarbudaya: Satu Perspektif Multidimensi. Jakarta: Bumi Aksara, 2013.

Suma, Muhammad Amin. Ulumul Qur'an. Jakarta: Raja Grafindo Persada, 2013.

Syihabuddin. Penerjemahan ArabIndonesia Teori Dan Praktek. Bandung: Humaniora, 2002.

Tim Penyusun Kamus Pusat Bahasa, Kamus Bahasa Indonesia. Jakarta: Pusat Bahasa, n.d.

Wehr, Hans. ..Arabic-English Dictionary: The Hans Wehr Dictionary of Modern Written Arabic. New York: Spoken Language Services, 1976.

Widjaja, H.A.W. Komunikasi: Komunikasi Dan Hubungan Masyarakat. Jakarta: Bumi Aksara, 2008.

Yoeti, Oka A. Ekonomi Pariwisata: Introduksi, Informasi, Dan Implementasi. Kompas Media Nusantara, 2008.

Yusuf, Pawit M. Komunikasi Instruksional: Teori Dan Praktek. Jakarta: Bumi Aksara, n.d.

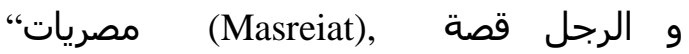

$$
\begin{aligned}
& \text { دورات ملصقات }
\end{aligned}
$$

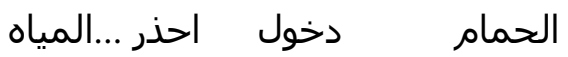

$$
\begin{aligned}
& \text { و بولندا و السعودية في الخاطئ }
\end{aligned}
$$




\author{
ليتوانيا Diakses Dari \\ Http://Masreiat.Com/Varieties/201 \\ 6/01/02/29757, Pada Tanggal \\ 13Februari 2018, Pukul 06.40 \\ WIB.," n.d.
}


